\title{
Blockchain Technology and How It Will Affect Accounting in the Future
}

\author{
Irena P. Pramono Intan Hardiningsih Semidang K. Putra Tiara C. Syahputra \\ Accounting Department, Universitas Islam Bandung \\ Tamansari 24-26, Bandung, West Java, Indonesia
}

\begin{abstract}
Rapid technology development nowadays brings out a major impact for many professions in the world. This phenomenon often called industrial revolution 4.0. This industrial revolution demand automation in various sectors, including in economic and financial sectors. In the financial sector, there is blockchain technology which becomes the basis technology of cryptocurrency and smart contract. This development could also affect the accounting profession, which required to follow technology development in the future. From this case, writers will discuss strength, weakness, opportunity, and the threat from the blockchain system and smart contract for accounting in the future. There will be a high demand for the blockchain system for companies since this technology make the transaction process could be more efficient, faster and secure. The research methodology that the writers use in this research is inductive reasoning with the qualitative method. The way data collected is using literature studies by using SWOT analysis framework.
\end{abstract}

Keywords: Blockchain, Technology, Accounting

DOI: $10.7176 /$ RJFA/11-10-06

Publication date:May $31^{\text {st }} 2020$

\section{Introduction}

The world is again confronted by massive changes in agriculture, manufacture, mining, transportation, and technology. The impact of this changes on social conditions, economic, and culture in this world. This changes is usually called the industrial revolution. Industrial revolution itself is a big change in human beings in the production process. Industrial revolution began in the 18th century. Until now the industrial revolution has entered 4 phases of change. The phase that occured was the industrial revolution 1.0, industrial revolution 2.0, industrial revolution 3.0, and what is running is industrial revolution 4.0. the changes that occur affect many aspects of life.

Before industrial revolution 1.0, humans produce just depends on muscle force, hydropower, and wind power. Until 1776, James Watt found a invention, it was steam engine. This invention has change the history. Production process became more effective and efficient. After that, industrial revolution 2.0 has happened in early 20th century. Before this second revolution, there are transportation process constraints. Until on the 1913 era, there are assembly line invention that use convenyor belt. The process change completely, the worker more being specialize with only taking care of the particular part.

After that there was an industrial revolution 3.0. in this era there were many changes in the production process. In this era, human power has been replaced. There are inventions such as machines, all-automatic devices, and all digitalization. This has brought changes not only in the field of industry, but also in the field of information.

And now, we have reached industrial revolution 4.0. The beginning of the industrial revolution 4.0 was first sparked by representatives of several experts from Germany in the Hannover trade fair event. Until the German government formed a special group to discuss industrial revolution 4.0. Now we are in the era of applying the concept of automation by machines. Where until now there has been the technology of the Internet of Things, Big Data, Artificial Intelligence and many other sophisticated technologies. And also everything has been connected by the internet so that the production process saves time, labor, and production costs.

The industrial revolution itself has spread in the financial sector. One of the industrial revolutions in the financial world is the technology known as Fintech. Fintech is defined as a term to refer to innovation in the financial sector that is given a modern twist. Another development technology in the financial sector is a technology called cryptocurrency. Cryptocurrency is a digital currency that is used for virtual transactions. Cryptocurrency is one of the technology application of blockchain system. Blockchain technology has a decentralized nature, which means there are no special parties that mediate including bank. Transactions are carried out peer to peer. All transactions on cryptocurrency are recorded and can be accessed by all people in the network. Blockchain technology is very tempting to be used by companies in the future since this technology offers cost efficiency (Fanning, 2016), secure data (Fanning, 2016), minimizing fraud and mistake (Liu, 2019) (Tan, 2019), and real time reporting (Karajovic, 2019).

Blockchain technology makes an automation that can disintegrate many professions and circumstances in the world. There will be a high demand for the blockchain system for companies since this technology make transaction process could be more efficient, faster and secure. If this happen in the future, one of the professions that will be affected most is the accounting professions. The risk that accountants will be replaced by computers 
will become a threat to accountants who will lose their role in the world. Therefore this research aims to discuss strength, weakness, opportunity, and the threat from the blockchain system for accounting in the future. Writers intend to analyze deeper and explain further in this research paper which entitled "Blockchain Technology, And How It Will Affect Accounting In The Future".

\section{Blockchain Technology}

\subsection{Blockchain History}

The idea of the blockchain can be traced back to 1991, where researchers named Stuart Haber and W. Scott Cornetta conducted a study, which produced a practical computerized way to register digital documents so that they could not be changed, or turned. The system used by the blockchain is a series of blocks that are cryptographically secured to store registered documents. In simple language, blockchain is a sequence of blocks which contained of information and locked, and that are chained with hash function.

In the beginning, the blockchain system was assessed as a threat and was called not having a safe system for the company. A common stigma is how a network can be managed by everyone while a large company is overwhelmed using the centralized method (Iqbalsweden, 2018). Nowdays the stigma is fading, thanks to the understanding and the increasing number of smart users about the blockchain concept. All the stigmas which were initially considered a threat, now turn into a great opportunity in technological progress (Iqbalsweden, 2018).

\subsection{Understanding Blockchain}

Blockchain is a digital transaction record based on its structure, in which individual records (blocks) are linked to each other in one list (chain). Blockchain is the base technology of cryptocurrency, such as bitcoin. On the blockchain, each block (a special area that accommodates all transaction changes) consists of hash, which is the identity of a digital data. Each block contains hashes from the previous block. (Onlinepajak, 2018).

Every block in this system is interrelated. If anyone wants to change data from one block, they must change data from other blocks as well. Each block protected by cryptography is interconnected to form a network (Onlinepajak, 2018). Initially the blockchain was used in the financial sector as an open, distributed and decentralized journal. Through a blockchain, transactions between one another will be more efficient than conventional transactions that still require intermediaries. (Onlinepajak, 2018).

In Indonesia, blockchain has been used by several companies in Indonesia. For example in the banking world, PT. Bank Central Asia has used the blockchain as an internal function to speed up payment transactions and reduce transaction constraints on the back office. (Onlinepajak, 2018). State-owned enterprises (BUMN) also already use blockchain technology, namely PT. Indonesian post. This freight forwarding company makes and develops Digiro.in, a checking service that adopts a blockchain system. (Onlinepajak, 2018).

Meanwhile in education system, blockchain has begun to be applied. One that applies the blockchain system in education is the Massachusetts Institute of Technology, USA. The application of the blockchain is still simple, especially in the issuance of electronic certificates that run on the blockchain system in the form of a ledger (Ledger Book) (Iqbalsweden, 2018).

One example of the application of blockchain in the world of education is absenteeism that applies. All activities that occur in class will be recorded. Starting from the presence of students, teachers, when they enter, as well as the material delivered in class. Later it will lead to transparency in the assessment. (Iqbalsweden, 2018). The application of the blockchain will also produce objectivity in the education system. For example, minimizing fraud such as the subjectivity of values, bribery, and tracking fake diplomas, which will reduce fraud in education. (Iqbalsweden, 2018).

Blockchain in general has an open and transparent nature, making it easier for individuals or groups to transact without limits, and have an impact on supporting the smooth operation of each user. This technology is well suited for the financial industry which involves many parties, such as banking. (Noviyanthi, 2017).

In its work, banks will experience significant changes if they use blockchain technology. For example, blockchain allows all transactions in banking to take place anywhere and anytime. Starting from the transfer, deposit and withdrawal of money, credit applications, international payments, etc. Of course this will streamline the user's time. (Noviyanthi, 2017). Blockchain will also open various profitable opportunities for banking. For example, the blockchain can make it easier for banks to analyze the background of customers who apply for credit or reduce the administrative costs of various transactions in banking. (Noviyanthi, 2017). One of the unique features in the blockchain is that transaction data that has already been entered cannot be changed or deleted. Therefore, fraud in transactions such as fraud, data forgery, or corruption can be avoided. (Noviyanthi, 2017). Cryptocurrency or often known as bitcoin and smart contract is one of the applications of blockchain technology in the financial sector. Cryptocurrency is a digital asset designed to work as an exchange medium that uses strong cryptography to secure financial transactions, control the creation of additional units, and verify asset transfers. The best-known crypto currency is bitcoin. In addition, there are crypto currencies from Indonesia such as tokenomy, agricoin, ana coin, etc. (Prastya, 2019). Meanwhile, smart contract is a computer program that directly 
controls the transfer of digital currencies or assets between parties under certain conditions. (Septiady, 2019). Smart Contract was originally created by a cryptographic expert, computer scientist, and also law scholar, Nick Szabo in 1994. Just like a conventional contract, a smart contract is basically a document that binds agreements, as well as agreements between several parties. However, unlike conventional contracts, smart contracts are coded stored in a blockchain. (Pratiwi, 2018).

\subsection{Big Four And Blockchain Application In Accounting}

Big Four is the largest accounting and professional services firm worldwide, offering auditing, lending, taxation, management consulting, advisory, actuarial and corporate finance services. Firms that are incorporated into the big four including PricewaterhouseCoopers (PWC), Deloitte, KPMG and Ernst \& Young (E\&Y). In 1979, there were 8 large public accounting firms known as 'big 8', big 8 was also the result of a combination of eight offices including:

1. Arthur Andersen

2. Arthur Young \& Company

3. Coopers \& Lybrand

4. Ernst \& Whinney

5. Deloitte, Haskins and Sells

6. KPMG (was formed due to the merger of Peat Marwick International and KMG Group)

7. Price Waterhouse

8. Touche Ross

In June 1989, Ernst \& Whinney decided to join Arthur Young and then formed Ernst \& Young. Then in August Deliotte, Haskins \& Sells merged with Touche Ross and later formed Deloitte \& Touche. Then the big 8 group changed to big 6 . Then in July 1998 Pricewaterhouse decided to join Coopers \& Lybrand and then formed the Pricewaterhouse Coopers accounting office. With the formation of Pricewaterhouse Coopers, big 6 turns into big 5 .

Big 5 consists of:

1. Arthur Andersen

2. Pricewaterhouse Coopers

3. Deliotte Touche Tohmatsu

4. Ernst \& Young

5. KPMG

In 2001 the Enron scandal occurred, this scandal involved Arthur Andersen's accounting firm, Arthur Andersen's accounting firm was indicted against the law for destroying documents relating to Enron's auditing and was considered covering up millions of losses in the Enron scandal. Because of this scandal, Arthur Andersen's accounting firm went bankrupt on a global basis. Partner offices all over the world under the banner of Arthur Andersen are all sold and most are joined to become other international accounting firms. With this incident, there are only four other international accounting firms known as the Big Four.

Big Four Companies are big players and have a big impact and influence in accounting professions. Big four Companies is a pioneer for public accounting firms in all over the world, the services provided by the big four are a picture or reference for public accounting firms in the world. Big four becomes a reference because it has the largest income and number of employees among other accounting firms. Big four research on blockchain, can be a picture that in the future blockchain can be a service that will be offered by the big four or even other accounting firms.

Table 1. Big Four companies Income and Employees in 2018

\begin{tabular}{|l|l|l|}
\hline Firms & Income & Employees \\
\hline Deloitte & \$43,2 Billion & 286.200 \\
\hline PwC & \$41,3 Billion & 250.930 \\
\hline EY & \$34,8 Billion & 260.000 \\
\hline KPMG & \$29,0 Billion & 207.050 \\
\hline
\end{tabular}

Source: compiled from various sources 
Table 2. Big Four Companies Biggest Client

\begin{tabular}{|l|l|l|l|}
\hline Big Four's Biggest Client & PwC & EY & KPMG \\
\hline Deloitte & Bank of America & Walmart & Accenture \\
\hline Microsoft & Goldman Sachs & Verizon & Halliburton \\
\hline Metlife & Prudential Financial & Coca cola & Citigroup \\
\hline Morgan Stanley & IBM & Intel Corp & Rolls Royce \\
\hline Berkshire Hathaway & 21st Century Fox & General Electric \\
\hline The Blackstone Group & Chevron &
\end{tabular}

Source: compiled from various sources

Blockchain technology application development was worked by big four companies since several years ago. It means blockchain technology application has already accepted by many multinational companies as their clients. Deloitte has Rubix and PwC has Vulcan as blockchain technology applications, meanwhile EY developed Know Your Customer (KYC) and KPMG developed Blockchain as a Service (BaaS).

In 2014, Deliotte began working on its own blockchain. Rubix is an application of Deloitte's blockchain technology, Rubix was created to facilitate and speed up the audit process (Karajovic, 2019). Deloitte utilizes a blockchain application for supply chain management. However, at this time Deloitte has created around 30 prototypes and pilot projects to address issues relating to digital identity and trade, international transactions and banking, and loyalty management and reward programs. The Irish Division opened Deliotte's first blockchain lab in May 2016. With this, Deliotte clearly understands the benefits of integrating blockchain technology in the provision of client services.

Currently PwC is testing different blockchain technologies and advising their clients about the various uses of their services regarding blockchain. PwC Australia cooperates with Netki, Bloq and Libra to create "Vulcan". Vulcan is a blockchain 'multi-asset' container developed to be able to exchange digital asset information to be exhibited with popular cryptocurrency, in other words, it is like a digital wallet, which is used for digital transactions. But the 'Vulcan' is still in the form of concepts. PwC also collaborates with BitSE to facilitate integration or integration in the Asia-Pacific market.

EY adopted an approach by experimenting on making an editable blockchain in collaboration with Accenture. Accenture believes that the blockchain that allows modification can be very useful in combating the unexpected. EY announced that it will release an identity management blockchain that is equipped with Know Your Customer (KYC) provisions for one of Australia's clients (Karajovic, 2019).

KPMG in collaboration with Microsoft has introduced a Digital Ledger service to advise clients on how blockchain can help improve transaction speed and security, reduce costs and digitize headquarters. This collaboration will be carried out by providing 'lifecycle support'. KPMG will help clients manage infrastructure blockchain installations. Blockchain as a Service is a service offered by KPMG, this service provides assistance to clients in installing blockchain.

\section{Literature Review}

Research on the blockchain has been carried out several times, mostly with literature and case study methods. Fanning and Centers in 2016 wrote about "Blockchain and Its Coming Impact on Financial Services". The author says the area that will be more affected by the blockchain is the back-office of the service. In making transactions, usually the recording will take a long time and a lot of process. This process involves contract negotiations with several legal parties and several parties to complete the transaction. With blockchain, this can be avoided, and of course can reduce the costs used (Fanning, 2016).

Tan and Low in his article titled Blockchain as the Database Engine in the Accounting System. Blockchain has implications for the accounting and auditing process (Tan, 2019). Implications for Accounting, blockchainbased accounting information systems, can change accounting and the role of accountants. Accountants will not be the main authorization on the accounting database, but they will have a new role in making the rules for the validation process and being the validator in the final choice. Nevertheless, accountants still have their initial roles. Namely, being a decision maker, especially in matters such as subjective amounts of balances written in financial statements, which cannot be determined instantly by transactions recorded in a blockchain-based accounting database. While the implications on auditing are partly because the permanent nature of the data in the block can reduce the level of fraud because of its imprint that is difficult to cover. However, it is too much when blockchain technology can eliminate error rates. Therefore, the role of auditing is still needed in blockchain-based accounting information systems. However, audit quality is expected to develop due to reduced error rates and fraud rates. Audit costs will also be reduced because of increased efficiency (Tan, 2019).

Another journal written by Karajovic mentioned one of the main sets of blockchain transparency. In addition, the blockchain also provides opportunities for triple-entry accounting, an automation system that confirms the accounting of debit/credit records for each group in each transaction to ensure reliable accounting. Then there is a smart contract that plays an important role in speeding up the recording process which directly updates account 
information and can track supply chain analysis in real time. This blockchain can benefit guarantee providers, advisors and organizational stakeholders, because blockchain users will later be able to check or ensure real-time recording. Blockchain can also minimize financing. With a blockchain, errors and inconsistencies can be reduced because all transactions will be recorded directly by the system in real-time. Furthermore Karajovic also mentioned that the criticism of the blockchain refers to the argument about the lack of standard regulations to be dissected, then about the regulations themselves which will not consider enough technological security to be widespread. Another issue that concerns the blockchain's ability regarding self-auditing and unchangeable systems, as well as the potential for the blockchain to completely replace the accounting profession (Karajovic, 2019).

Most notably, According to Karajovic, blockchain creates an opportunity for triple-entry accounting (Karajovic, 2019), whereby the system automatically confirms the debit/credit entries recorded by each party in a transaction to ensure bookkeeping reliability. Two well-known start-ups for creating this triple-entry software are Balanc3 and TriplEntry. Triple-entry accounting could become integral to the accounting industry by providing a tertiary destination that automatically verifies transactions for bookkeeping. Triple entry accounting is a term for a new method of accounting, that was proposed in the 1980's. It was more recently popularized when Ian Grigg associated it with blockchain technology. The third entry in the system, entered into the blockchain, is both a receipt and a transaction. This is where blockchain comes in: instead of these entries being recorded separately in independent sets of ledgers, they occur in the form of a transfer between wallet addresses in the same distributred, public ledger, creating an interlocking system of permanent and objective accounting records. Triple entry is quite a confussing term because we are not creating a third entry, we just linking two saparate double entries. That link is created via smart contract that works to ensure that the two double entries in saparate legal entities are always the same, this is auto enforced by the smart contract and as with all smart contracts it is tamper proof.

A study by O'Leary in 2017 said that the blockchain can make accountants reduce their authority because the blockchain provides opinions on the accuracy of financial statements. Another comment states that because of the blockchain, auditors and accounting firms will 'disappear'. On the supply chain, blockchain also leads to similar opinions. Some commentators have argued that the blockchain will 'renew' the supply chain, while others claim that the blockchain is a 'game changer' for the supply chain. Then there is a misunderstanding about how the blockchain works in regulating transaction processes, such as accounting, supply chain, and other arrangements (O'Leary, 2017).

A research by Liu in 2019 said that blockchain offers the new way torecord, process, and financial transaction and information, has the potential to change the acconting profession and business ecosystem. There are some implication of blockchain to auditing and elaborate opportunities and challenges to auditors. By making specific recommendations for auditors to adapt, adjust, and elevate themselves to the role of strategic partners in blockchain implementation. (Liu, 2019).

A research by Tumasjan \& Beutel said that The emergence of blockchain as a peer-to-peer technology is the question of how blockchain technology may be adopted depending on individuals attitudes and their environment. They analyzed adoption patterns across eight scenarios in the short term and in the long term. They found that users expectations and attitudes was a crucial role for the adoption. (Tumasjan \& Beutel, 2019).

\section{Research Methodology}

The research methodology that the writers use in this research is inductive reasoning. This research aims to provide study literature about how blockchain technology application in accounting system goes so far. By using SWOT analysis framework, this research try to clasiffy each information into categories which are Strenght, Weakness, Opportunity, and Threat about blockchain technology application in accounting process.

SWOT analysis aims to present different perspectives from internal and external factors, which can affect business planning in a company, so that the planning can run according to its path (Pahlevi., 2018). According to Pahl \& Richter, the SWOT analysis is a tool for a analysis situation, the abbreviation SWOT stands for strengths, weaknesses, opportunities, and threats. The SWOT analysis provides a frame work that a company must align internal activities with external realities to be successful. (Pahl \& Richter, 2007).

The origins of the SWOT analysis can be traced in the 1960s and 1970s, where a researcher named Albert Humphrey, conducted research at Stanford University using information from large companies. The purpose of the research is to find the cause of the failure of the company's planning. The result of this research is an analysis called SOFT analysis. Humphrey and his research team used the category "What is good in the present is Satisfactory; good in the future is an Opportunity; bad in the present is a Fault; and bad in the future is a Threat ". In 1964, researchers named Urick and Orr changed F to W, and until now the SOFT analysis continues to be the SWOT analysis (Nyarku, 2011).

\section{Results and Discussion}

From the discussion above, in chapter 2, there are several pros and cons of blockchain implementation in business and accounting process. In this chapter, this pros and cons then divided into 4 categories, which are strenght, 
weakness, opportunity and threat or known as SWOT. This SWOT analysis used to understand the internal and external factors that can be either support and dissuade blockchain adaptation process in accounting process and give a description about the risk and the benefit to the accounting profession.

Table 3. SWOT Framework of Blockchain Application

\begin{tabular}{|c|c|c|c|}
\hline Strength & Weakness & Opportunity & Threat \\
\hline $\begin{array}{l}\text { Secure data } \\
\text { (Fanning, 2016) } \\
\text { Because the data } \\
\text { already encrypted }\end{array}$ & $\begin{array}{l}\text { Permanent data, makes it } \\
\text { hard to change a data } \\
\text { when needed. (Fanning, } \\
\text { 2016) (Liu, 2019) }\end{array}$ & $\begin{array}{l}\text { Minimum transaction cost reduce } \\
\text { the market price (Fanning, 2016) }\end{array}$ & $\begin{array}{l}\text { Could reduce } \\
\text { accountant work field } \\
\text { (Fanning, 2016) }\end{array}$ \\
\hline $\begin{array}{l}\text { Minimize fraud } \\
\text { because the data } \\
\text { cannot be changed } \\
\text { (Fanning, 2016), } \\
\text { (Tan, 2019) (Liu, } \\
2019 \text { ) }\end{array}$ & $\begin{array}{l}\text { Huge R\&D cost because } \\
\text { blockchain can be } \\
\text { considered as a new } \\
\text { technology (Fanning, } \\
\text { 2016) }\end{array}$ & $\begin{array}{l}\text { Data transparancy } \quad \text { (Fanning, } \\
\text { 2016) }\end{array}$ & $\begin{array}{l}\text { No regulations from the } \\
\text { goverment (Fanning, } \\
\text { 2016). } \\
\text { existing regulations do } \\
\text { not fully regulate } \\
\text { blockchain, and } \\
\text { blockchain security } \\
\text { (Karajovic, 2019). }\end{array}$ \\
\hline $\begin{array}{l}\text { Fast transaction } \\
\text { (Fanning, 2016) }\end{array}$ & & $\begin{array}{l}\text { Accountant will have a new role in } \\
\text { making the rules and the system } \\
\text { for the validation process (Tan, } \\
\text { 2019) (Liu, 2019) }\end{array}$ & $\begin{array}{l}\text { Accountants will not be } \\
\text { the main authorization } \\
\text { on the accounting } \\
\text { database (Tan, 2019) } \\
\text { (O'Leary, 2017) }\end{array}$ \\
\hline $\begin{array}{l}\text { Full control for the } \\
\text { user (Fanning, } \\
2016 \text { ) }\end{array}$ & & $\begin{array}{l}\text { Minimize the reconciliation } \\
\text { process (Liu, 2019) }\end{array}$ & $\begin{array}{l}\text { The existence of self- } \\
\text { auditing could threaten } \\
\text { the accounting } \\
\text { profession (Karajovic, } \\
2019 \text { ) }\end{array}$ \\
\hline \multirow[t]{5}{*}{$\begin{array}{lr}\text { Near } & \text { real-time } \\
\text { financial } & \text { reporting } \\
(\text { Liu, } & 2019) \\
(\text { Karajovic, } 2019) \\
\end{array}$} & & $\begin{array}{l}\text { There is no centralized authority } \\
\text { to verify the existence, ownership } \\
\text { and measurement (Liu, 2019) }\end{array}$ & \\
\hline & & $\begin{array}{l}\text { Triple entry accounting as the } \\
\text { consquences of the blockchain } \\
\text { technology used to make system } \\
\text { automatically run and make sure } \\
\text { that ledger could be trusted. } \\
\text { (Karajovic, 2019) }\end{array}$ & \\
\hline & & $\begin{array}{l}\text { The existence of smart contracts } \\
\text { could increase transparency, } \\
\text { could reduce tax violations or } \\
\text { errors. (Karajovic, 2019) }\end{array}$ & \\
\hline & & $\begin{array}{l}\text { Audit costs will also be reduced } \\
\text { (Tan, 2019) }\end{array}$ & \\
\hline & & $\begin{array}{l}\text { Reduce the reconciliation cost } \\
\text { (Liu, 2019) }\end{array}$ & \\
\hline
\end{tabular}

Source: compiled from various sources

From the table above, we wan conclude that the strenghs of blockchain application in accounting process would be ensure the data more secure according to Fanning (2016) because the data will be encrypted, minimize the fraud because it is impossible to change the data (Fanning, 2016) (Tan, 2019) (Liu, 2019), offer faster transaction (Fanning, 2016) which also means it will reduce the transaction cost, audit cost, and reconciliation cost (Fanning, 2016) (Tan, 2019) (Liu, 2019) and near real-time financial reporting (Liu, 2019) (Karajovic, 2019). There are also opportunities that can occur with blockchain technology application, such as in the future accountant are estimated to have a new role in making the rules and the system for the validation process (Tan, 2019) (Liu, 2019). This technology will also minimize the reconciliation process (Liu, 2019) since there will be no report differences between the bank and the company. Triple entry accounting will be used do to the use of blockchain technology in accounting (Karajovic, 2019). Increasing of transparency, could also reduce tax violations or errors. (Karajovic, 2019). 
Permanent data as inherent nature of blockchain technology makes it hard to change a data when needed (Fanning, 2016) (Liu, 2019) will be a weakness. Likewise huge R\&D cost will become another weakness of blockchain application, because blockchain can be considered as a new technology and it takes time to familiarize this technology (Fanning, 2016). Meanwhile as this technology provide a new chance for accountant to develop, this technology also gives a threat to accountant work in technical field such as clerk, and auditor profession will shift to audit system work rather than financial audit.

\section{References}

Anwar, H. (2018, May 24). 101 BLOCKCHAINS. Retrieved from https://101blockchains.com/introduction-toblockchain-features/

Fanning, K. \&. (2016). Blockchain and Its Coming Impact on Financial Services. The Journal of Corporate Accounting \& Finance, 53-57.

Iqbalsweden. (2018). Blockchain, Solusi Dunia Pendidikan Masa Kini. Retrieved from Steemit: https://steemit.com/indonesia/@iqbalsweden/blockchain-solusi-dunia-pendidikan-masa-kini

Karajovic, M. K. (2019). Thinking outside the block: projected phase of blockchain integration in the accounting industry. . Australian Accounting Review, 1-12.

Liu, M. W. (2019). How Will Blockchain Technology Impact Auditing and Accounting: Permissionless Vs. Permissioned Blockchain. Current Issues in Auditing. Current Issues in Auditing.

Noviyanthi, D. A. (2017, January 5). Blockchain, Financial Technology, dan Masa Depan Industri Perbankan di Indonesia. Retrieved from Microsoft: https://news.microsoft.com/id-id/2017/01/05/blockchain-financialtechnology-dan-masa-depan-industri-perbankan-di-indonesia/

Nyarku, K. \&. (2011). ediscovering SWOT Analysis: The Extended Version. Retrieved from www.researchgate.ne: https://www.researchgate.net/publication/279060225_Academic_Leadership_Journal_Rediscovering_SWO T_Analysis_The_Extended_Version

O'Leary, D. E. (2017). Configuring blockchain architectures for transaction information in blockchain consortiums: The case of accounting and supply chain systems. . Intelligent Systems in Accounting, Finance and Management, 138-147.

Onlinepajak. (2018, October 5). Blockchain dan Pemanfaatannya di Indonesia. Retrieved from Online Pajak: https://www.online-pajak.com/blockchain

Pahl, N., \& Richter, A. (2007). Swot Analysis - Idea, Methodology and a Practical Approach.

Pahlevi. (2018, June 21). Pengertian SWOT. Retrieved from www.pahlevi.net: https://www.pahlevi.net/pengertian-swot/

Perbanas. (2017). Retrieved from https://dosen.perbanas.id/hadirnya-inovasi-teknologi-dibidang-keuangan-2/

Prastya, Y. (2019, March 18). 5 Mata Uang Kripto Asal Indonesia. Retrieved from Seputar Forex: https://www.seputarforex.com/artikel/5-mata-uang-kripto-asal-indonesia-287788-38

Pratiwi, K. (2018, March 15). Mengenal Konsep Smart Contract dan Kontroversinya. Retrieved from Techinasia: https://id.techinasia.com/smart-contract-dan-kontroversinya

Septiady. (2019, September 15). Apakah Smart Contract Itu? Retrieved from Crypto Harian: https://cryptoharian.com/apakah-smart-contract-itu/

Tan, B. S. (2019). Blockchain as the Database Engine in the Accounting System. Australian Accounting Review, 315-317.

Tumasjan, A., \& Beutel, T. (2019). Blockchain-Based Decentralized Business Models in the Sharing Economy: A Technology Adoption Perspective. In H. Treiblmaier, \& R. Beck, Business Transformation through Blockchain (pp. 77-115). Cham: Springer Nature Switzerland AG.

www.barantum.com. (2019). Pengertian Blockchain dan Panduan Lengkap Blockchain! Retrieved from Barantum: https://www.barantum.com/blog/blockchain-adalah/ 